\title{
Timing Citrus and Avocado Foliar Nutrient Applications to Increase Fruit Set and Size
}

\author{
Carol J. Lovatt ${ }^{1}$
}

ADDITIONAL INDEX WORDS. boron, sodium tetraborate, nitrogen, urea, phosphorus, potassium phosphite

\begin{abstract}
Summary. The goal of this research was to identify the role essential nutrients play in the physiology of tree crops, and then to apply the nutrient as a foliar fertilizer to stimulate a specific metabolic process at phenological stages when nutrient demand is high. This approach has proven successful. A single winter prebloom foliar application of nitrogen as low-biuret urea [0.16 kg N/ tree (0.35 lb N/ tree)] to 30-year-old 'Washington' navel orange (Citrus sinensisL. 0 sbeck) trees during flower initiation significantly increased yield and fruit number per tree for each of 3 consecutive years $(P \leq 0.05)$. The number of commercially valuable largesize fruit also increased significantly with yield increases $\left(r^{2}=0.88\right)$. Sodium tetraborate applied foliarly to ' $\mathrm{H}$ ass' avocado (Persea americana $\mathrm{M}$ ill.) trees at the cauliflower stage of inflorescence development (elongation of inflorescence secondary axes, pollen and ovule development) increased the number of pollen tubes reaching the ovule, ovule viability and cumulative yield ( $\mathbf{P} \leq \mathbf{0 . 0 5}$ ). Additional examples are presented.
\end{abstract}

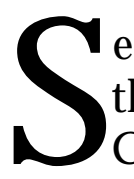

easonal cycles of flowering, fruit set and fruit development for the 'Washington' navel orange and ' $\mathrm{H}$ ass' avocado growing in California are depicted in Figs. 1 and 2. Fruit set (early fruit drop) is the most critical stage of fruit development from the grower's point of view. It is during this period that the greatest gains in fruit retention influencing final yield can be made. Events during this period also impact fruit size and quality. In both crops, flowering and fruit set, periods of high nutrient demand, occur when soil temperatures are low. Soil temperatures are generally $\leq 15^{\circ} \mathrm{C}\left(59^{\circ} \mathrm{F}\right)$ from January to A pril in citrus and avocado growing areas of California (H amid et al., 1988). L ow soil temperature reduces root metabolic activity, solubility of nutrients in the soil solution and nutrient transport in the transpiration stream. Thus, the ability of trees to utilize nutrients applied to the soil is dependent on many factors unrelated to nutrient demand. With increased use of sprinkler, drip or microjet irrigation systems, there is a growing trend to divide the annual amount of fertilizer to be applied into 6 to 12 small monthly applications.

\footnotetext{
I thank the graduate students, postdoctorates and technicians in my laboratory whose research contributed to this paper: A. Ali, J. Corona, K. H ake, G. H amid, I. J aganath, O. Sagee, S. Salazar-Garcia, L. Summers, and Y. Zheng. The cost of publishing this paper was defrayed in part by the payment of pagecharges. U nder postal regulations, this paper thereforemust behereby marked advertisement solely to indicate this fact.

${ }^{1}$ Professor of plant physiology, D epartment of B otany and Plant Sciences, U niversity of California, Riverside, CA 92521-0124. E-mail: carol.lovatt@ucr.edu.
} 
While this strategy reduces the potential for groundwater nitrate pollution, it ignores tree phenology and nutrient demand. In foliar fertilization, the nutrient must be taken up by leaves of the crop, or other target organs, and be phloem mobile. Foliar fertilization with nutrientsmeeting thesecriteriaisconsidered to be 5 to 30 times more efficient than soil fertilization depending on the nutrient, crop and soil in which thecrop isgrowing (PureG ro, n.d.). M oreover, foliar fertilization can betimed to meet the tree's demand for a nutrient. $\mathrm{H}$ ere we report optimal stages in citrus and avocado tree phenology when foliar application of nitrogen, phosphorus or boron resulted in increased yield and/ or fruit size and, in the case of citrus, increased ratio of total soluble solids to acid.

\section{Citrus}

Embleton and J ones (1974) demonstrated that regardless of the fertilization method maximum nutritionally attainable yields for sweet oranges annually required between 0.45 and $0.60 \mathrm{~kg} \mathrm{~N} /$ tree (0.99 and $1.32 \mathrm{lb} \mathrm{N} /$ tree).

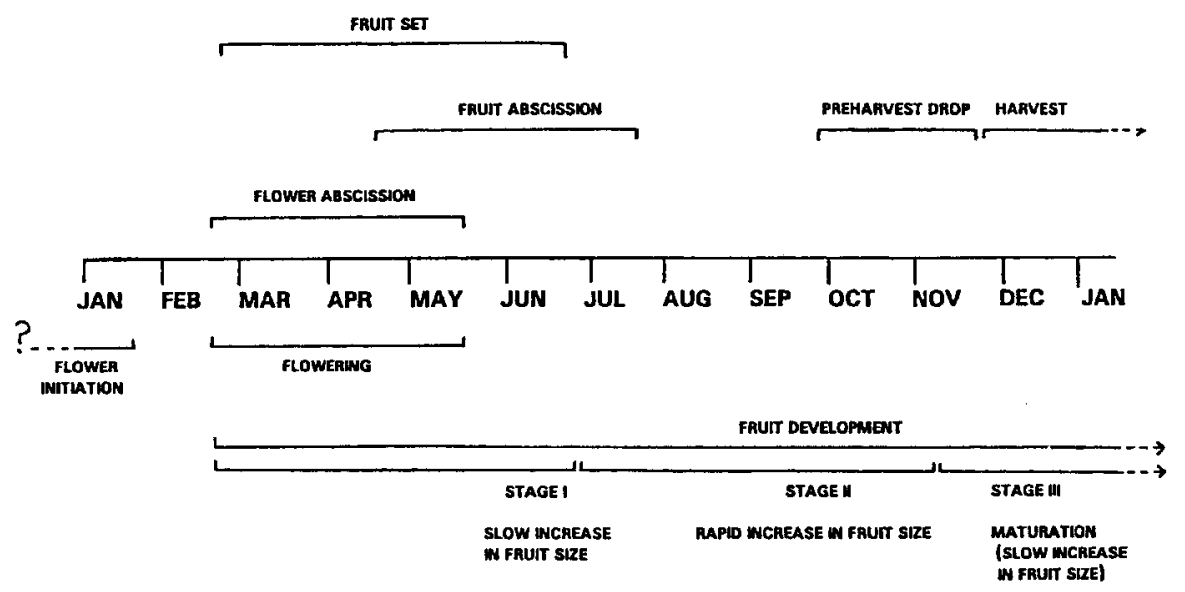

Fig. 1. Phenology model of the navel orange based on 25-year-old 'W ashington' navel orange ( $C$ itrus sinensis $L$. O sbeck) trees on 'T royer' citrange [Poncirus trifoliate ( $L$. $R$ af) $\times C$. sinensis] rootstock at $R$ iverside, C alifornia.

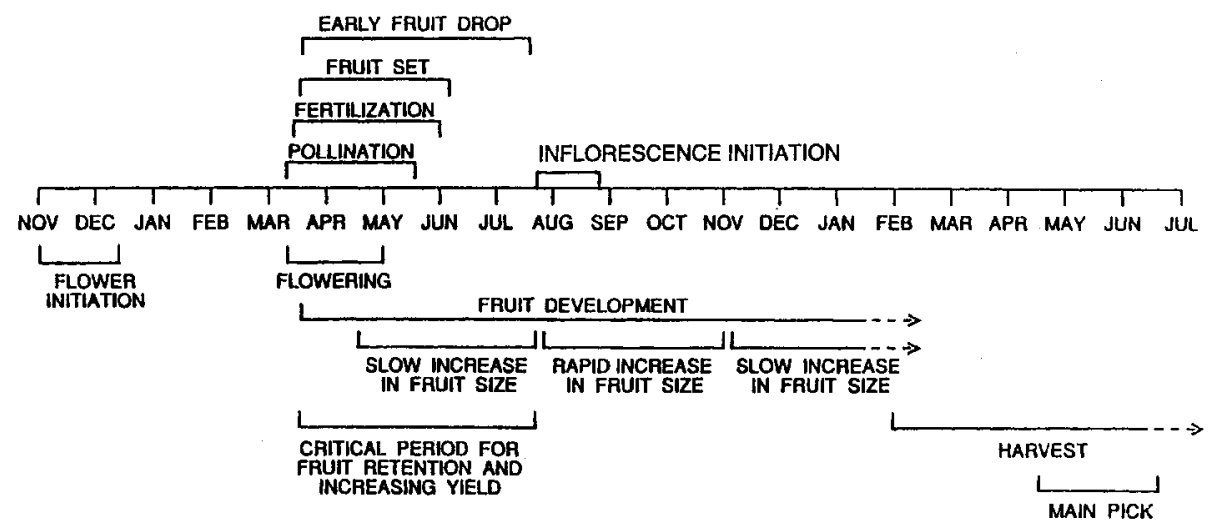

Fig. 2. Phenology model of the 'H ass' avocado (Persea americana Mill.) based on environmental conditions for southern C alifornia.
Despite this, foliar nitrogen fertilization was not widely adopted commercially. D ue to the potential for ammonia toxicity, there is a limit in the amount of nitrogen that can be applied in a single application, necessitating a minimum of three annual sprays to supply the recommended rate of nitrogen. I n contrast, earlier results of Sharplesand H ilgeman (1969) suggested foliar applications of urea at the appropriate time might increase yield. For 7 years, yields of ' $V$ alencia' orangetrees receiving only $0.23 \mathrm{~kg} \mathrm{~N} /$ tree $(0.51 \mathrm{lb} \mathrm{N} /$ tree) split between two foliar applications of urea, one in early F ebruary and a second in lateA pril to early $M$ ay, produced yields that were statistically equal to thoseobtained with much higher rates [ 0.45 or $0.91 \mathrm{~kg} \mathrm{~N} /$ tree $(0.99$ or $2.01 \mathrm{lb} \mathrm{N} /$ tree)] of soil-applied ammonium nitrate. The objective of our research wasto identify specific times in the phenology of the navel orangetree when a single foliar application of low-biuret urea at $0.16 \mathrm{~kg} \mathrm{~N} /$ tree $(0.35 \mathrm{lb} \mathrm{N} /$ tree) could economically increase yield and/ or fruit size compared to soil-applied nitrogen. Theoverall goal is to motivate growers to replace soilapplied nitrogen with foliar nitrogen fertilization to reduce the potential for groundwater nitrate pollution.

Theefficacy of asinglefoliar application of low-biuret urea during one of three phenological stages was tested in four commercial navel orange orchards. The effect of applying urea to the canopy at prebloom (prior to or during flower initiation) or at full bloom wasquantified with the objective of increasing fruit set and yield in southern California orchards where yields average $30 \mathrm{t} \cdot \mathrm{ha}^{-1}$ (12 ton/ acre) (California Agricultural Statistics Service, 1991). Previous research in our lab provided evidence of a relationship between ammonia (a breakdown product of urea), and itsmetabolites, and flowering and fruit set in citrus. When stress treatments that promote flowering in citrus were reduced in duration (i.e., 4 instead of 8 weeks of lowtemperature treatment) or severity (i.e., deficit-irrigated instead of withholding irrigation), foliar-applied low-biuret urea $(0.16 \mathrm{~kg} \mathrm{~N} /$ tree) raised the tree ammoniastatusand increased both thenumber of inflorescences per tree and flowers per inflorescence, but not the number of vegetative shoots (Lovatt et al., 1988a, 1988b). Wesubsequently demonstrated that the metabolism of ammonia to arginine and arginine to polyamines were linked in navel orange flowers and developing fruit (Sagee and L ovatt, 1991) and provided evidence of the role of specific polyamines in low-temperature stressinduced flowering in navel orange (Ali and Lovatt, 1995). D eveloping flowers and 
Table 1. Effects of a winter prebloom foliar application of low-biuret urea on yield of the 'W ashington' navel orange, 3-year average and 3-year cumulative yield. ${ }^{2}$

\begin{tabular}{|c|c|c|c|c|}
\hline \multirow{2}{*}{$\begin{array}{l}\text { Month urea } \\
\text { applied }\end{array}$} & \multirow{2}{*}{$\begin{array}{c}\text { Yield } \\
\text { (kg/tree) }^{y}\end{array}$} & \multicolumn{2}{|c|}{ F ruit no./tree } & \multirow{2}{*}{$\begin{array}{c}\text { 3-year } \\
\text { cumulative } \\
\text { yield } \\
\text { (kg/tree) }\end{array}$} \\
\hline & & All sizes & $7.0-8.0 \mathrm{~cm}^{\mathrm{x}}$ & \\
\hline None (control) & $85 b^{w}$ & $542 b$ & 172 a & $256 \mathrm{~b}$ \\
\hline N ovember & $102 \mathrm{a}$ & $657 a$ & $188 \mathrm{a}$ & $305 a$ \\
\hline D ecember & 103 a & 661 a & $211 a$ & 308 a \\
\hline January & 113 a & 761 a & $190 \mathrm{a}$ & 338 a \\
\hline February & 107 a & 708 a & 198 a & 321 a \\
\hline Significance & $P \leq 0.001$ & $P \leq 0.01$ & NS & $P \leq 0.001$ \\
\hline \multirow{2}{*}{\multicolumn{5}{|c|}{$\begin{array}{l}{ }^{2} \mathrm{Ali} \text { and } \mathrm{L} \text { ovatt (1994). } \\
\mathrm{y}_{1} \mathrm{~kg}=2.2 \mathrm{lb} \text {. } \\
{ }^{\times} \mathrm{cm}=0.39 \text { inches. } \\
\text { wM eans within a column followed by different letters are significantly different by } \mathrm{D} \text { uncan's multiple range test at } \mathrm{P} \leq 0.05 \text {. } \\
\text { Ns } \mathrm{N} \text { onsignificant at } \mathrm{P} \leq 0.05 \text {. } \\
\text { T able 2. E ffect of a winter prebloom foliar application of low-biuret urea on yield of the } \\
\text { 'W ashington' navel orange. }\end{array}$}} \\
\hline & & & & \\
\hline \multirow[b]{2}{*}{ Month urea applied } & & \multicolumn{2}{|c|}{ Yield ( kg fruit/tree) } & \\
\hline & & Year 1 & Year 2 & Year 3 \\
\hline N one (control) & & $109 b^{x}$ & $32 \mathrm{c}$ & $116 \mathrm{~b}$ \\
\hline November & & $125 \mathrm{a}$ & $42 \mathrm{abc}$ & $140 \mathrm{a}$ \\
\hline D ecember & & $129 a$ & $38 \mathrm{bc}$ & $143 a$ \\
\hline January & & 132 a & 48 a & 159 a \\
\hline February & & 127 a & $46 a b$ & $150 \mathrm{a}$ \\
\hline Significance & & $P \leq 0.05$ & $P \leq 0.05$ & $P \leq 0.01$ \\
\hline
\end{tabular}

zAli and Lovatt (1994).

$\mathrm{y}_{1} \mathrm{~kg}=2.2 \mathrm{lb}$.

XM eans within a column followed by different letters are significantly different by $D$ uncan's multiple range test at $P \leq 0.05$.

of maximum peel thickness) was tested with the goal of stimulating cell division to increase fruit size in two orchardsin theSan J oaquin Valley of California, where yields average $60 \mathrm{t} \cdot \mathrm{ha}^{-1}(24$ ton/ acre) (CaliforniaAgricultural Statistics Service, 1991).

WiNTER PREBLOOM FOLIAR N. For thethree successive harvests, from 1990 through 1992, Ali and Lovatt (1994) successfully increased fruit set and yield of the 'Washington' navel orange with a single foliar winter prebloom application of low biuret urea. A final concentration of $0.5 \%$ $\mathrm{N}$ [asU nocal Plus (U nocal, Brea, C alif.), $20 \% \mathrm{~N}, 0.1 \%$ biuret], provided $0.16 \mathrm{~kg}$ $\mathrm{N} /$ tree (T able 1). Control trees received $0.5 \mathrm{~kg} \mathrm{~N} /$ tree (1.10 lb N/tree) as urea (granules, $0.25 \%$ biuret) applied to the soil in winter ( $N$ ovember to J anuary). Single foliar applications of urea were made on 15 N ov., 15 Dec., 15 Jan.

postpetal fruit borne on leafy inflorescences were characterized by significantlyhigher polyamineconcentrations, faster growth ratesand agreater percent fruit set than those borne on leafless inflorescences (Lovatt et al., 1992). Foliar application of low-biuret urea at full bloom significantly increased concentrations of ammonia, arginine and polyamines and fruit growth rate and

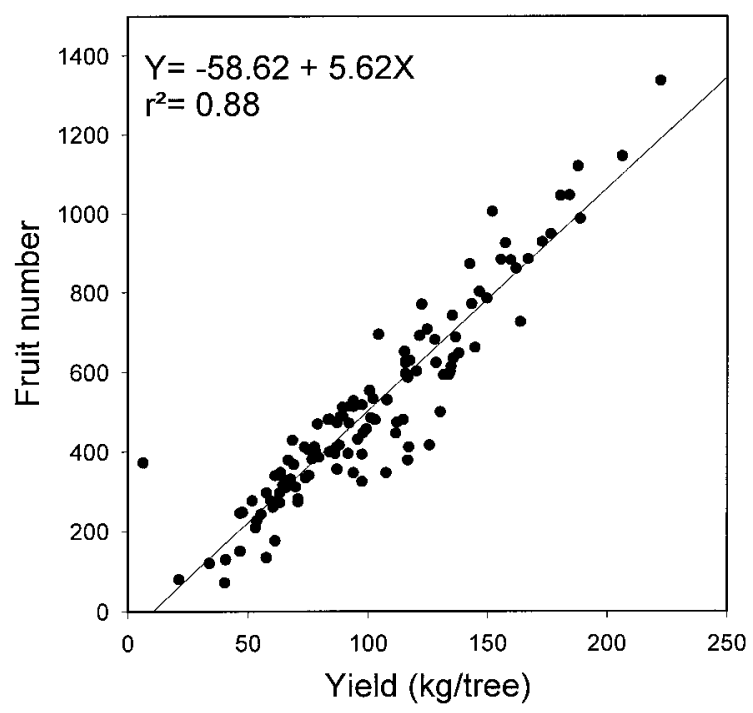

size by June for fruit of leafy inflorescences (Corona, 1994). L ast, based on the well established role of polyamines in promoting growth by cell division and on our finding that foliar-applied urea stimulated polyamine biosynthesis, we hypothesized that a foliar application of low-biuret urea at the end of the cell division stage of fruit growth might increase the cell division rate or extend the length of the cell division period of fruit growth, and thus increase fruit size without increasing fruit set. Theend of the cell division stage of fruit growth in navel orange is associated with the time the peel is at its maximum thickness. The effect of a foliar application of urea at the end of the cell division stage of fruit growth (time

Fig. 3. Yield (kg/tree) vs. number of navel orange fruit with diameters of 6.1 to $8.0 \mathrm{~cm}(2.4$ to 3.1 inches) per tree averaged over 3 years of the study $(1 \mathrm{~kg}=2.2 \mathrm{lb}$ ). or $15 \mathrm{Feb}$. The foliar applications made on $15 \mathrm{~J}$ an. or $15 \mathrm{Feb}$., the approximate time of irreversiblecommitment to flowering and flower initiation for the southern California orchard in which the research was conducted (Lord and Eckard, 1987), significantly increased yield all 3 years of the study $(P \leq 0.05)$ (Table 2). Applications of foliar urea made on $15 \mathrm{~N}$ ov. or $15 \mathrm{D} \mathrm{ec}$. increased yield 2 of the 3 years $(P \leq 0.05)$. Yield increases were not accompanied by a decrease in fruit size. Asthetotal weight of fruit per tree increased in response to foliar-applied urea, the number of fruit of commercially valuable size also increased (Fig. 3). Yield increases were not due to improved nitrogen status of trees receiving a foliar application of low-biuret urea. All trees had optimum levels of $\mathrm{N}$ and other nutrientsthroughout the experiment according to annual September leaf analyses. There was no significant relationship between tree nitrogen status and yield (Table 3). Time of foliar urea application significantly affected cumulative yield. In each year of thisstudy, the winter prebloom foliar application of low-biuret urea was costeffective (Ali and L ovatt, 1992). Janu- 
T able 3. Linear regression analysis of leaf nitrogen content (\%) and fruit weight ( $\mathrm{kg})$ per tree.

\begin{tabular}{lccc}
\hline $\begin{array}{l}\text { Independent } \\
\text { variable (X) }\end{array}$ & $\begin{array}{c}\text { Dependent } \\
\text { variable (Y) }\end{array}$ & $\begin{array}{c}\mathbf{P} \\
\text { value }\end{array}$ & $\begin{array}{c}\text { C oefficient of } \\
\text { linear correlation }\end{array}$ \\
\hline N itrogen & Fruit weight per tree & 0.78 & 0.026
\end{tabular}

'Ali and L ovatt (1994)

ary or February foliar-applied urea resulted in net cumulative (3 years) increases in yield over the control of 20.6 and 16.4 t. ha ${ }^{-1}$ (8.3 and 6.6 ton/ acre), respectively.

Full-bloOM Foliar N. At full bloom low-biuret urea (asU nocal Plus, $20 \% \mathrm{~N}$, $0.1 \%$ biuret) was applied to fully cover the canopy of 'Washington' navel orange trees at a final concentration of $1.3 \% \mathrm{~N}$ providing $0.16 \mathrm{~kg} \mathrm{~N} /$ tree. All treeshad optimum levelsof $\mathrm{N}$ and other nutrients throughout the experiment according to annual September leaf analyses. Thetreatment significantly increased both total weight and number of fruit per tree in the "on" year ( $P \leq$ 0.10 ), but not in the "off" year (Table 4). Combining the full bloom application of urea with an application of cytokinin (proprietary material) at full bloom and $30 \mathrm{~d}$ later significantly increased total weight of fruit per tree both years of the study $(P \leq 0.10)$. As yield increased so did the number of commercially valuable large-size fruit [transverse diameter 7.0 to $8.0 \mathrm{~cm}(2.8$ to 3.1 inches)] ( $P \leq 0.05$ ) (Fig. 4). The two treatments resulted in a net increase in cumulative yield ( 2 years) over the control of 7 and 11 t.ha-1 (2.8 and 4.4 ton/ acre), respectively. B oth treatmentswere cost-effective.

END OF CELL DIMSION STAGE OF FRUIT GROWTH. About 1 week or 3 weeks past petal fall low-biuret urea (as U nocal Plus, 20\%N , 0.1\%biuret) wasapplied to provide full coverage of 'F rost nucellar' navel orange trees at a final concentration of $1.5 \% \mathrm{~N}$ to provide $0.16 \mathrm{~kg} \mathrm{~N} /$ tree. Both treatments significantly increased the number of large-size fruit [transverse diameter 8.1 to $8.8 \mathrm{~cm}(3.2$ to 3.5 inches) ] in a single, but different, year of the 3 -year study $(P \leq 0.05)$. I $n$ an attempt to improve the efficacy of the treatment, the time of maximum peel thickness, which marks the end of the cell division stagefor navel oranges, was determined experimentally for orchards from southern coastal $C$ alifornia to the northern citrusregion of the San J oaquin Valley for both "on" and "off" crop years. $M$ aximum peel thicknessoccurred between 17 J une and 27 J uly. Based on this result, low-biuret urea (granules, $46 \% \mathrm{~N}, 0.25 \%$ biuret) was applied to 'Frost nucellar' navel orange trees at a final concentration of $1.5 \% \mathrm{~N}$ to provide $0.16 \mathrm{~kg} \mathrm{~N} /$ tree during mid-M ay or mid-July. This study included phosphorus, another nutrient that would be in high demand during cell division, and, a nutrient known to increase fruit quality by increasing soluble solids per hectare and the ratio of total soluble solids to acid in the juice (E mbleton et al., 1973). Phosphorus was applied to the foliage as potassium phosphite [N utri-Phite(Biagro, Visalia, Calif.), 028-26] at a rate of $6 \mathrm{~L} \cdot \mathrm{ha}^{-1}$ (0.64 gal/ acre) in mid-M ay or mid-July or as two applications at $4.6 \mathrm{~L} \cdot \mathrm{ha}^{-1}(0.49 \mathrm{gal} /$ acre) in mid-M ay and mid-J uly. All trees had optimum nutrient concentrations according to annual September leaf analyses. The July application of urea and the doubleapplication of potassium phosphitein $\mathrm{M}$ ay and J uly weretheonly treatments that significantly increased the number of commercially valuable large-size fruit [ transverse diameter 6.9 to $7.4 \mathrm{~cm}$ (2.7 to 2.9 inches), 7.5 to 8.0 $\mathrm{cm}$ (3.0 to 3.1 inches), and 8.1 to 8.8 cm (3.2 to 3.5 inches), packing carton sizes 88,72 , and 56 , respectively] (Table 5). In addition, thesetwo treatments had higher total weight (nonsignificant) and number of fruit $(P \leq 0.10)$ per tree. The doubleapplication of potassium phosphite al so significantly increased total soluble solids $(P \leq 0.001)$ and the ratio of total soluble solids to acid $(P \leq 0.01)$ by early $N$ ovember compared to control fruit. By this date, fruit from trees receiving the two foliar applications of potassium phosphite had a ratio of 8.1 compared to a ratio of 7.2 for control fruit. A minimum ratio of 8.0 is required for navel harvest in California. T otal soluble solids $(P \leq 0.04)$ and the ratio of total soluble solids to acid $(P \leq 0.01)$ remained significantly higher in fruit from trees treated with potassium phosphite than control fruit $30 \mathrm{~d}$ later.

\section{Avocado}

Research using boron to increase fruit set and yield of crops requiring pollination and fertilization has been extensive. Reportsin theliteraturedocument the positive effect of boron on pollen germination; growth of the pollen tube to the ovule; gametogenesis; and cell division during the early stages of fruit development (Lovatt and Dugger, 1984). Yield increases were achieved in response to added boron even for trees with adequate boron levels ( $H$ anson, 1991). B oron sprays were most effective when cool, wet weather predominated during flowering, conditions that reduce bee activity and pollination (H anson, 1991). In South Africa, R obbertseetal. (1990, 1992) demonstrated that when pistils harvested from avocado trees receiving a boron foliar application were pollinated with pollen from trees also sprayed with boron, pollen germination and pollen tube

T able 4. Effect of foliar applications of low-biuret urea (full bloom) and cytokinin (full bloom $+30 \mathrm{~d}$ later) on the yield of 'W ashington' navel orange.

\begin{tabular}{|c|c|c|c|c|c|}
\hline \multirow{3}{*}{$\begin{array}{l}\text { U rea applied } \\
\text { at full bloom }\end{array}$} & \multirow{3}{*}{$\begin{array}{l}\text { Cytokinin applied } \\
\text { at full bloom + 30 d }\end{array}$} & \multicolumn{4}{|c|}{ Yield } \\
\hline & & \multicolumn{2}{|c|}{ "On" year } & \multicolumn{2}{|c|}{ "Off" year } \\
\hline & & kg/tree & no./tree & kg/tree & no./tree \\
\hline Control (untreated) & & $157 b^{x}$ & $981 \mathrm{~b}$ & $53 \mathrm{~b}$ & $336 \mathrm{~b}$ \\
\hline+ & - & $182 \mathrm{a}$ & 1198 a & $57 \mathrm{~b}$ & $380 \mathrm{~b}$ \\
\hline+ & + & $181 \mathrm{a}$ & $1146 a b$ & $73 a$ & 448 a \\
\hline
\end{tabular}

zAli and Lovatt (1994).

$\mathrm{y}_{1} \mathrm{~kg}=2.2 \mathrm{lb}$.

xM eans within a column followed by different letters are significantly different by $D$ uncan's multiple range test at $P \leq 0.10$. 


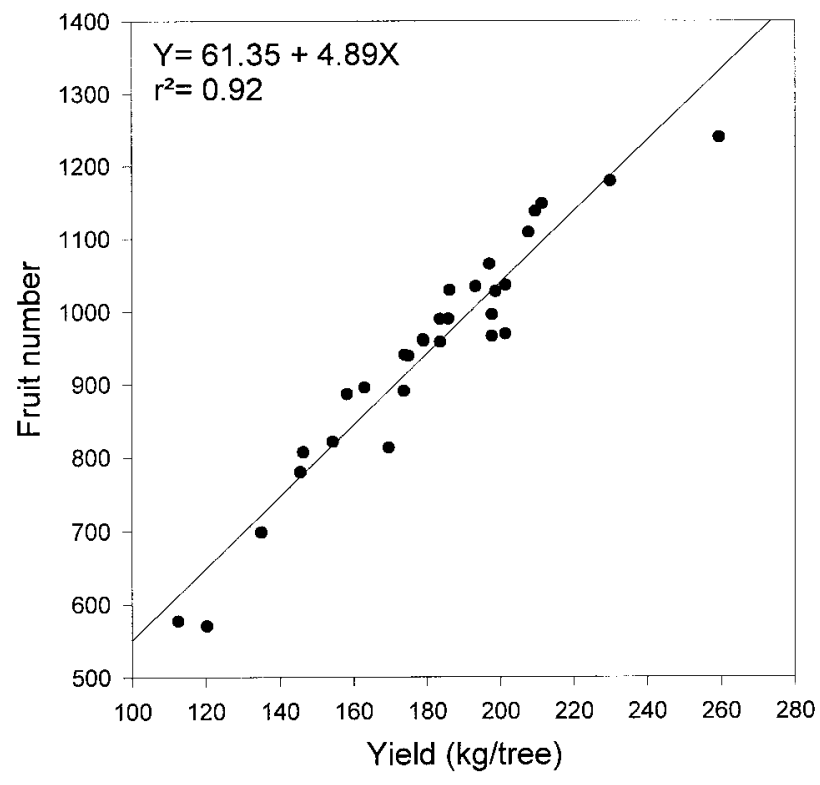

Fig. 4. Yield (kg/tree) vs. number of navel orange fruit with diameters 6.4 to $8.8 \mathrm{~cm}$ ( 2.5 to 3.5 inches) per tree averaged over 2 years of the study ( 1 $\mathbf{k g}=\mathbf{2 . 2}(\mathrm{lb})$.

growth were significantly better than in flowers from untreated trees. H owever, statistically significant yield increases in response to foliar-applied boron were only achieved in some orchards and in some years (C oetzer et al., 1993). Evidence that nitrogen increased ovule viability of applewasreported byWilliams (1965).

Cauliflower stage foliar b and $\mathrm{N}$. D uring the cauliflower stage of avocado inflorescence development, boron (sodium tetraborate, Solubor, $20.5 \%$ B), and/ or low-biuret urea (U nocal Plus, $20 \% \mathrm{~N}, 0.1 \%$ biuret), was applied to commercial ' $\mathrm{H}$ ass' avocado treesto provide $6 \mathrm{gB} /$ tree $(0.2 \mathrm{oz} \mathrm{B} /$ tree), or 0.16 $\mathrm{kg} \mathrm{N} /$ tree(J aganath and L ovatt, 1998). All trees had optimum nutrient levels based on annual September leaf analyses. The cauliflower stage is character- ized by elongation of thesecondaryinflorescence axes of the inflorescenceand pollen and ovule development within the flowers (Salazar-Garcia et al., 1998). Boron significantlyincreased the number of pollen tubes that reached the ovule for open-pollinated ' $\mathrm{H}$ ass' avocado trees in a commercial orchard, and increased ovule viability and cumulative yield in the commercial orchard $(P \leq 0.05)$ (Tables 6 and 7) (J aganath and Lovatt, 1998). U rea significantly increased the number of viable ovules and number of pollen tubes that successfully reached theovule and increased cumulative yield ( $P \leq$ 0.05) (Tables 6 and 7) (Jaganath and L ovatt, 1998). Foliar-applied boron or urea resulted in a net increase in cumulative ( 3 years) yield over the control of 12.2 and 11.0 t.ha-1 ${ }^{-1} 4.9$ and 4.4 ton/ acre), respectively. (This research will include five harvests when completed.) The increased cumulative yield was accompanied by an increase in the number of commercially valuablelarge-sized fruit. Treatments were cost-effective. The combined foliar application of boron plus urea, despite having positive effects on the number of pollen tubes that successfully reached the ovule and on ovule viability (Table 6), significantly increased the number of flowers with double pistils $(P \leq 0.05)$ and had no effect on yield (Table 7). At the cauliflower stage of inflorescence development, foliar fertilization is more effectivethan asoil application. R obbertse et al. (1992) reported that root absorp- tion of boron was restricted in spring. The results of Jaganath and L ovatt (1998) indicate that it is necessary to spraythedeveloping inflorescence. They obtained yield increases with foliar-applied boron, but could not increase yield with trunk injections of boron at the cauliflower stage even though trunk injectionsincreased tree boron statusto a greater degree than foliar sprays. U rea also must be applied directly to inflorescences because mature leaves of the ' $\mathrm{H}$ ass' avocado under southern $\mathrm{C}$ alifornia conditions do not take up urea (N evin et al., 1990). Based on our results (J aganath and L ovatt, 1998) and those of R obbertse et al. (1992), boron isused asafoliar bloom spray by growers to increase yield in years in which adverse climatic conditions might reduce pollen tube growth and ovule viability.

\section{Conclusions}

Winter and spring foliar fertilizer applications likely increase fruit set and yield becausenutrientsessential forflowering and fruit set are limiting due to reduced transpiration and/ or nutrient acquisition by roots when air and/ or soil temperatures are low. The key has been, however, to identify the specific nutrient elements to be applied and the role each plays in fruit set and development in order to determine the optimal time to apply the nutrient to stimulate a specific physiological process. O ur previous research provided evidence that foliar urea applied during or after a lowtemperature or water-deficit period increased citrusflowering by elevating the ammoniastatusof thetree ( $L$ ovatt et al., 1988a, 1988b) and increased the polyamine content, growth rate, and size of developing citrus fruit, as well as their potential to set (Corona, 1994; Lovatt et al., 1992). The mechanism by which fruit size was increased by foliar application of ureaor potassium phosphite

T able 5. E ffect of low-biuret urea and potassium phosphite applied to the foliage of 'F rost nucellar' navel orange in J uly or May and July, respectively, on yield and number of fruit per tree of packing carton sizes 88,72, and 56 .

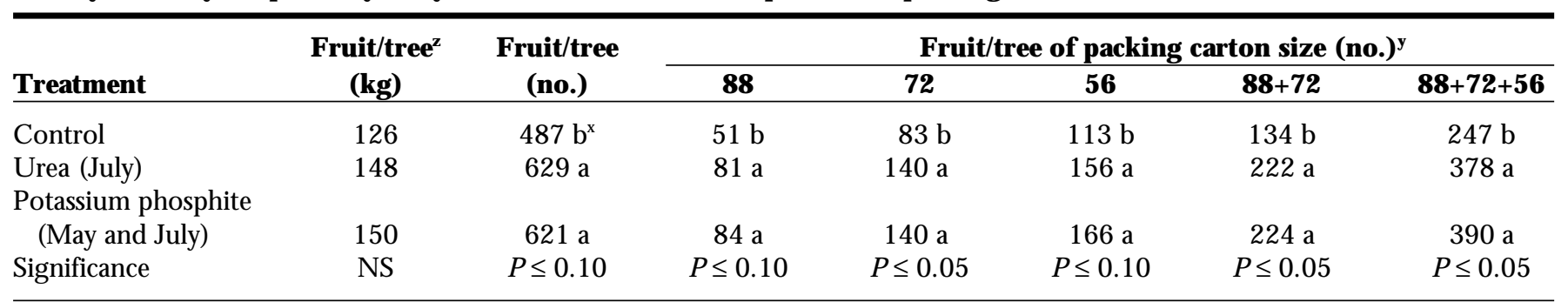

$\mathrm{z} 1 \mathrm{~kg}=2.2 \mathrm{lb}$.

ypacking carton sizes 88,72 and 56 correspond to fruit with transverse diameters $6.9-7.4 \mathrm{~cm}(2.7-2.9$ inches), $7.5-8.0 \mathrm{~cm}(3.0-3.1$ inches), and $8.1-8.8 \mathrm{~cm}$ (3.2-3.5 inches), respectively.

xM eans within a column followed by different letters are significantly different by $D$ uncan's multiple range test at $P \leq 0.05$. 
T able 6. Effect of boron and/or urea applied to the foliage of ' $\mathrm{H}$ ass' avocado trees in the field at the cauliflower stage of inflorescence development on number of pollen tubes penetrating the ovule and percent viable ovules. ${ }^{z}$

\begin{tabular}{lcc}
\hline Treatment & $\begin{array}{c}\text { Pollen tubes (no.) } \\
\text { penetrating the ovule }\end{array}$ & \begin{tabular}{c} 
Viable ovules $_{(\%)}$ \\
\hline Control
\end{tabular} \\
Boron & $0.77 \mathrm{c}^{\mathrm{w}}$ & $70 \mathrm{~b}$ \\
U rea & $2.29 \mathrm{a}$ & $81 \mathrm{a}$ \\
Boron turea & $1.48 \mathrm{~b}$ & $88 \mathrm{a}$ \\
\hline
\end{tabular}

J aganath and Lovatt (1998).

yD ata are the average for 30 samples per treatment.

${ }^{\times D}$ ata are the average for 20 samples per treatment.

wM eans within a column followed by different letters are significantly different by Tukey'S HSD at $P \leq 0.05$.

T able 7. Effect of boron and/or urea applied to the foliage of ' $\mathrm{H}$ ass' avocado trees at the cauliflower stage of inflorescence development on yield. ${ }^{2}$

\begin{tabular}{lcccc}
\hline & \multicolumn{4}{c}{ Yield (kg fruit/tree) $^{\mathbf{y}}$} \\
\cline { 2 - 5 } Tear $\mathbf{1}$ & Year 2 & Year 3 & C umulative \\
\hline Control & $69 \mathrm{a}$ & $82 \mathrm{~b}$ & $41 \mathrm{a}$ & $192 \mathrm{~b}$ \\
Boron & $67 \mathrm{a}$ & $134 \mathrm{a}$ & $41 \mathrm{a}$ & $242 \mathrm{a}$ \\
U rea & $99 \mathrm{a}$ & $89 \mathrm{~b}$ & $47 \mathrm{a}$ & $237 \mathrm{a}$ \\
Boronturea & $56 \mathrm{a}$ & $87 \mathrm{~b}$ & $43 \mathrm{a}$ & $186 \mathrm{~b}$ \\
\hline
\end{tabular}

Jjaganath and Lovatt (1998).

Y $D$ ata are the average value for 16 individual tree replicates per treatment. Values in each vertical column followed by different letters are significant by Tukey'S H SD at $P \leq 0.05(1 \mathrm{~kg}=2.2 \mathrm{lb})$.

at the end of the cell division stage of fruit growth (identified by maximum thickness of peel) remains to be determined. The increased ratio oftotal solublesolidsto acid injuiceoffruitfrom treestreated with foliar sprays of potassium phopshite is the reported response of citrusfruit to increased phosphorus nutrition (Embleton et al., 1973). The results of our research identified three stages in the phenology of the citrus tree when foliar applied urea $\mathrm{N}$ can be used to increase yield or fruit size. In general, low-biuret urea applied during the period from flower initiation through fruit set significantly increased yield without reducing fruit size, whereas applications made at the end of the cell division stage of fruit development (time of maximum peel thickness, mid-June through end of July in California) significantly increased fruit size without affecting yield. Each foliar ureaapplication provided 25 to $33 \%$ of the annual $\mathrm{N}$ required by sweet oranges for maximum yield (Embleton and Jones, 1974). The treatments were cost-effective and reduced the potential for nitrate pollution of the groundwater. Either boron or urea, as afoliar spray at the cauliflower stage of inflorescence development of ' $\mathrm{H}$ ass' avocado trees, increased the number of pollen tubes penetrating theovuleand thenumber of viableovules. T aken together, these results provide evidencethatspecificnutrientsapplied foliarly can efficiently meet tree nutrient demand

roots treated with oxamyl. Proc. 6th Intl. Citrus Congr. 2:993-1004.

$H$ anson, E. J. 1991. Boron requirement and mobility in tree fruit species. Current Topics Plant Bioch. Physiol. 10:240-246.

Jaganath, I. and C.J. Lovatt. 1998. Efficacy studieson prebloom canopy applications of boron and/ or ureato 'H ass' avocado. Proc. 3rd (1995) World Avocado Congr. 1:181-184.

Lord, E.M . and K.J. Eckard. 1987. Shoot development in Citrussinensis L. (Washington navel orange). II. Alteration of developmental fate of flowering shootsafter $\mathrm{GA}_{3}$ treatment. Bot. Gaz. 148: 17-22.

Lovatt, C.J. , O. Sagee, and A.G. Ali. 1992. Ammonia and/ or its metabolites influence flowering, fruit set, and yield of the 'Washington' navel orange. Proc. Intl. Soc. Citricult. 1:412-416.

L ovatt, C.J . and W.M . D ugger. 1984. Boron, p. 389-421. In: E. Frieden (ed.). Thebiochemistry of the essential ultratraceelements. Plenum Publishing Corp., N ew York.

Lovatt, C.J., Y. Zheng, and K.D. $\mathrm{H}$ ake. 1988a. Demonstration of a change in nitrogen metabolism inand stimulate specific physiological processesresulting in increased yield, fruit size and quality.

\section{Literature cited}

Ali, A.G. and C.J. Lovatt. 1995. Relationship of polyaminesto low-temperaturestress-induced flowering of the 'Washington' navel orange (Citrus snensisL. O sbeck). J. H ort. Sci. 70:491-498.

Ali, A.G. and C.J. L ovatt. 1992. Winter application of foliar urea. Citrograph 78:7-9.

Ali, A.G. and C.J. L ovatt. 1994. Winter application of low biuret urea to the foliage of 'Washington' navel orange increased yield. J. Amer. Soc. H ort. Sci. 119:1144-1150.

CaliforniaAgricultural Statistical Service. 1991. California fruit and nut statistics. Calif. Agr. Stat. Serv., Sacramento.

Coetzer, L.A., P.J. Robbertse, and B.P.H .J anseVan Vuuren. 1993. The role of boron in avocados: Theory, practice, and reality. S. Afr. Avocado G rowers' Assn. Yrbk. 16:2-4.

Corona, J.C. 1994. Relationship of polyamines to fruit set and growth of the 'Washington' navel orange [Citrus sinensis (L.) O sbeck]. MS thesis, U niv. California, Riverside.

Embleton, T.W. and W.W. Jones 1974. Foliarapplied nitrogen for citrus fertilization. J. Environ. Q ual. 3:338-392.

Embleton, T.W., W.W. Jones, C.K. Labanauskas, and W.J. Reuther. 1973. Leaf analysisisa diagnostic tool and guide to fertilization, p. 183-211. In: W.J. Reuther (ed.). The citrus industry. vol. 3. U niv. of California, D iv. of Agr. Sci., Berkeley.

H amid, G.A., S.D. Van Gundy, and C.J. Lovatt. 1988. Phenologies of the citrusnematode and citrus fluencing flower initiation in citrus. Isr. J. Bot. 37:181-188.

L ovatt, C.J., Y. Zheng, and K.D. H ake. 1988b. A new look at the Kraus-Kraybill hypothesis and flowering of citrus. Proc. 6th Intl. Citrus Congr. 1:475483.

N evin, J.M ., C.J. L ovatt, and T.W. E mbleton. 1990. Problems with urea-N foliar fertilization of avocado. Acta H ort. 2: 535-541.

PureG ro Company. n.d. Soil vs. foliar. PureG ro Co., Sacramento, Calif.

Robbertse, P.J., L.A. Coetzer, and F. Bessinger. 1992. Boron: U ptake by leaves and influence on fruit production. Proc. 2 nd World Avocado Congr. 1:173-178.

Robbertse, P.J ., L.A. Coetzer, M. Slabbert, and J.J. Bezuidenhout. 1990. The influence of boron on fruit set in avocado. Acta H ort. 275:587-594.

Sagee, O . and C.J . L ovatt. 1991. Putrescineconcentration parallels ammonia and arginine metabolism in developing flowers of 'Washington' navel orange. J. Amer. Soc. H ort. Sci. 116:280-285.

Salazar-Garcia, S., E.M. Lord, and C.J. Lovatt. 1998. I nflorescence and flower development of the ' $\mathrm{H}$ ass' avocado (Persea americana Mill.) during "on" and "off" crop years. J. Amer. Soc. H ort. Sci. 123:537-544

Sharples, G.C. and R.H . H ilgeman. 1969. Influence of differential nitrogen fertilization on production, trunk growth, fruit size and quality and foliage composition of ' $V$ alencia' orange trees in central Arizona. Proc. 1st Intl. Citrus Symp. 3:1569-1578.

Williams, R.R. 1965. The effect of summer nitrogen applicationson thequality of appleblossom. J. H ort. Sci. 40:31-41. 